\title{
SZTAFETA \\ Z POCHODNIAMI
}

Norbert Elias zamyka swój młodzieńczy tekst na temat widzenia w naturze obrazem uroczystej procesji z pierwszej księgi Platońskiego Państwa. Oto o zmierzchu wyruszają z Pireusu jeźdźcy z pochodniami, które podają sobie $z$ rąk do rąk, rozpraszając blaskiem płomieni mrok nadchodzącej nocy. Jedni drugim przekazuja światło - lampadia echontes diadosousin allelois - co Elias bierze za figurę wychowania, rozwoju nauki i kultury. Każde pokolenie przekazuje swoim uczniom i następcom dar wiedzy rozświetlającej drogę do doskonałości.

Nie przypadkiem cytowana powyżej Platońska fraza była z upodobaniem wykorzystywana jako motto instytucji i przedsięwzięć edukacyjnych. Współczesne nauki dumnie wywodzą swój ród od Platona (i Arystotelesa), kreśląc wizję sukcesji myśli, w której przekazywane z rąk do rąk światło starożytnych opromienia nasze dzisiejsze dokonania, uszlachetnia je i uwzniośla, a przy okazji - legitymizuje. Fraza „Już w starożytnej Grecji...” znalazłaby się z całą pewnością na wysokim miejscu na liście najpopularniejszych incipitów prac dyplomowych.

Chcemy więc wierzyć, że tak cenne dla nas nauki, filozofia i sztuka - czyli duch europejski - zrodziły się w Grecji, czy też, jak pisze Bruno Snell, zostały tam odkryte. Grecję utożsamiamy przy tym chętnie z Atenami okresu klasycznego, Ateny $-\mathrm{z}$ demokracją, a demokrację $-\mathrm{z}$ agora, w ten sposób kreśląc linię sukcesji dochodzącą do naszych czasów i naszych problemów. Takie ujęcie daje się łatwo wytłumaczyć ogólnoludzką potrzeba poszukiwania szacownych genealogii. Nie poprzestajemy jednak na konstatacji, że Grecy występują gdzieś w naszym drzewie rodowym. Twierdzimy ponadto, że są wciąż w pewien sposób żywo obecni w naszej dzisiejszej myśli. W szczególny sposób dotyczy to nauk humanistycznych i społecznych. 
Przekonanie o aktualnej obecności Greków szczególnie wyraźnie daje się zauważyć w filozofii i socjologii polityki, gdzie grecka polis ciagle funkcjonuje jako nieodzowny punkt odniesienia. Alvin Gouldner w błyskotliwej pracy Enter Plato (1965), której fragment zamieszczono w tym numerze, broni tezy o greckim pochodzeniu nauk społecznych, w czym sekunduje mu w krytycznym komentarzu Michał Kaczmarczyk. A zatem: Grecy wiecznie żywi, bo wiecznie aktualna jest myśl społeczna? Jeśli tak, warto postawić pytanie o granice tej aktualności, poza którymi zaczynaja się instrumentalizacja i fałsz.

Dowolne kształtowanie przeszłości to przywilej, ale i pilna potrzeba teraźniejszości, o ile chce ona w historii poszukiwać argumentów. Trzeba było odpowiednio sprokurować Greków, by wyzyskać ich potencjał retoryczny i erystyczny na potrzeby XX-wiecznej myśli politycznej. Dotknęło to, jak wiadomo, zwłaszcza Sokratesa, którego postać dostarcza nader wdzięcznego materiału do trawestacji. Nad tradycja sokratejską zastanawiają się Paweł Armada i Dominika Michalak w recenzji The Art of Living Alexandra Nehamasa. Elias natomiast w studenckiej farsie z 1930 roku pod wiele mówiącym tytułem „Polityka jako nauka” przedstawia Sokratesa jako wziętego, choć bezproduktywnego edukatora; trudno oprzeć się wrażeniu, że rola ta doskonale oddaje charakter jego obecności w naszym myśleniu.

Wciaganie starożytnych Greków w teraźniejszość to jedna ze strategii ich udomawiania - inna jest ubieranie ich w kostiumy $\mathrm{z}$ teatrzyku szkolnych mitologii i relegowanie w oswojoną przeszłość. To kusząca metoda zwłaszcza w wypadku trudniejszych do przyswojenia elementów dziedzictwa greckiego, takich jak starożytna religijność, o której spreparowanym wizerunku pisze Lucyna Kostuch. Świat Greków z krwi i kości, mówiących językiem, którego znajomości dawno przestaliśmy wymagać od kolejnych pokoleń komentatorów Platona, okazuje się niepokojąco obcy. Przywykliśmy do szkolnych Greków odziedziczonych po klasycyzmie, romantyzmie, Fryderyku Nietzschem i Hannah Arendt; niekoniecznie jesteśmy zainteresowani bezpośrednim kontaktem.

Dotyczy to zresztą nie tylko Greków sprzed tysiącleci - współcześni też są tajemnica, tym większa, że okrywa ich szczelnie draperia przeszłej chwały. Przemysław Kordos prowadzi nas w świat współczesnych zmagań literackich z antyczna tradycja, pokazując, jak współcześni Grecy z trudem spłacają odsetki od długów Homera, Sofoklesa i Arystofanesa. Maria Mycielska-Środoń przedstawia z kolei problemy tożsamości greckiej w warunkach emigracji. W jej tekście zarysowuje się bolesny dla małych narodów problem kruchości wielkiej tradycji, która łatwo staje się tylko 
krępującą etykietką. Niełatwo być potomkiem Ulissesa. Na szczęście jednak, o czym łatwo zapominamy, spuścizna antyku to nie jedyne źródło dzisiejszej tożsamości greckiej. Ewa Nowicka pokazuje aspekt zupełnie inny - ludową religijność prawosławną widzianą z perspektywy antropologicznej. Pamiętajmy: nie zostało z góry ustalone, która z odkrywanych dziś warstw ma być kluczem do greckiej kultury. Warto zdobyć się na dystans wobec skłonności do uprzywilejowywania tylko jednej z wielu bogatych tradycji obszaru, który dziś nazywa się Grecja.

Tym z naszych czytelników, którzy zechcą na chwilę oderwać się od pytania o żywotność Greków i pogrążyć w wirze bieżących polemik, proponujemy jak zwykle obszerny blok recenzji. Znajda w nim między innymi dyskusję o konserwatyzmie Tomasza Merty oraz polemikę Tomasza Zaryckiego z Janem Sową na temat „fantomowego ciała króla”. Ucieczka w teraźniejszość nie ustrzeże nas jednak przed Mojra. Nie tylko pisząc o przyszłości demokracji, lecz i o dystynkcji klasowej, rytuałach interakcyjnych oraz strategiach życiowych robotników w kapitalizmie, pozostajemy częścią wielkiego łańcucha idei, który łączy nas - badaczy społecznych, humanistów $-\mathrm{z}$ antykiem. To ciężkie kajdany, lecz w ich ogniwach zaklęta jest nasza zbiorowa tożsamość.

Nie jest prawda, że wiemy o Grekach choćby tyle, ile sądzimy, że wiemy. Większość naszych wyobrażeń na ich temat to uproszczenia i mistyfikacje. Nasza tożsamość nie tkwi jednak w treści tych półprawd, lecz w znaczeniu, jakie z nimi wiążemy. Z pokolenia na pokolenie przekazujemy sobie przekonanie, że w jakimś stopniu - choćby znikomym - wszyscy jesteśmy Grekami. Warto pamiętać, że nie ma nic koniecznego w takim stosunku do przeszłości, który nakazuje traktować ją jako wiążącą i ważna, zakorzeniać się w niej i zadomawiać, a nawet przedkładać ją ponad chwilę obecna. Ten stosunek do Greków i dziedzictwa klasycznego w ogólności jest jednym z najintymniejszych składników naszego europejskiego projektu samych siebie, który - ponieważ nie jest konieczny - możemy łatwo zatracić. Jeśli więc wciąż nam na nim zależy, powinniśmy go bronić, podtrzymując, rewidując i przekształcając konstruowany od dwóch tysiącleci fikcyjny obraz Grecji. Przekazując go sobie z rąk do rąk, podajemy kolejnym pokoleniom światło, które - jak chcemy wierzyć - po raz pierwszy zapłonęło w Grecji. Czyli nigdzie.

Marta Bucholc 